\title{
Empirical Determination of Property Assets Management Styles in South-Western Nigeria Hotels
}

\author{
Olufemi Daniel Durodola \& Samuel Adesiyan Oloyede \\ Department of Estate Management, School of Environmental Sciences \\ College of Science and Technology, Covenant University, Ota, Ogun State, Nigeria \\ E-mail: dan_ass2007@yahoo.com,samoloye49@yahoo.com
}

\begin{abstract}
A survey was conducted on probabilistically determined 57 hotels of various 'stars' in South-Western geo-political zone of Nigeria. The study investigates hotels' property assets management styles with a view to fashioning out appropriate management methodology and develop an integrated resource management framework. Data were collected from hotel organizations' management, general managers, staff and customers. Information obtained was complemented by the physical assessment of hotel structures and system operations. Stratified sampling technique backed by cluster sampling was used. Descriptive statistics was employed for statistical analysis. Findings showed that maintenance management predominates in the industry while facilities management is just filtering in with emphasis on facilities benchmarking. Property management is not favoured at all. The study recommends that Nigeria Tourism Development Corporation should develop a framework for quality assurance policy improvement among hotels in Nigeria. By so doing, hotel management companies and intending property development and management companies would be guided and buoyed into doing things beyond benchmarking.
\end{abstract}

Keywords: Facilities Management, Facilities Benchmarking, Maintenance Management, Property Management, Quality Assurance

\section{Introduction}

Hotel investors, just like any property investor, are interested in the trinity of investment objectives which are preservation of capital, enhancement of its value and the earning of net cash profit on the capital invested. The realisation of the objectives is anchored to putting in place a proactive asset management style so as to maximise the potentials of available assets. From estate management perspective, the major management styles available in the running of property assets are maintenance management, property management and facilities management. Milohnic and Cerovic (2007) identified benchmarking as another property asset management style that could be used in running hotel facilities. Arditi and Nawakorawit (1999) define maintenance as the preservation of a building so that it can serve its intended purpose. Building maintenance, according to British Standard 3811 ('Glossary' 1984), defines 'maintenance' as 'work undertaken in order to keep or restore a facility to an acceptable standard'. Seeley (1976) asserted that 'building maintenance' is of great significance to the economy of any nation not only because of the scale of expenditure involved, but also because it is important to ensure that the nation's stock of buildings, both as a factor of production and of accommodation, is used effectively as much as possible.

The College of Estate Management (1995) defines 'property management' as "the application of management principles to property assets with the aim of maximizing their potentials',

Property management focuses on tenant selection and letting; control over the estate, rent review and lease renewals, insurance of the properties, repairs, services and service charges, property management records, property marketing and portfolio management. Property management is more than maintenance management in that maintenance is an aspect of property management. Its aim is to secure optimum return on the invested capital although the return need not always be financial but may be in terms of social benefit or status enhancement (Nwankwo, 2004). The hallmark of property management is portfolio management and its performance.

Barett (2000) regarded facilities management as "an integrated approach to operating, maintaining, improving, and adopting the buildings and infrastructure of an organization in order to create an environment that strongly supports the primary objectives of that organization'. Hamer (1988) opined that the facilities managers, in the course of their duties, are concerned with inventory management, requirements programming, master planning, location and layout planning, drafting, cost accounting, real estate strategy, move coordination, project administration and implementation, purchasing coordination, maintenance planning, site management and overall system coordination. Spedding and Homes (1999) were of the opinion that the major goal of facilities management 
is to ensure that the support services of an organization are packaged and managed in such a way that the core activity of the organization is achieved excellently. A variant of facilities management is facilities' benchmarking which essentially is the application of benchmarking principles to facilities operation, management and development. Benchmarking is a technique for identifying best practice in a specified key business or manufacturing process, in order to improve performance and competitiveness. Essentially in hotel operations, the process involves identifying the ways other successful hotel organizations are doing specific operations, compare same with the way such a process is being run internally, identify the variance and then implement it as much as possible. According to Bode-Thomas (2003); Okungbowa (2005) and Olusola-Obasa (2005), the aspiration of Nigerians is that facilities maintenance and sustenance need be geared up in all sectors of the economy, hotels inclusive. Thus, it is essential for existing assets to be properly managed if the business is to maintain the capital invested, enhance its value and sustain reasonable returns. To give fillip to the tourism sector of the economy as a veritable and dependable source of foreign exchange, there is the need to explore available strategy to make hotel sector of the economy more vibrant. Hotels and motels are special real estate investments. According to Sirota (2004), investing in the hotel business involves heavy financial outlay and sustainable supporting facilities. Hotels, according to Then (2000), is a specialized property investment area. For this reason, estate surveyors and valuers' knowledge and understanding of prevalent assets' management styles will go a long way in fashioning out appropriate management methodology. It will also assist in developing an integrated resource management framework. The paper is structured into four major segments namely the empirical studies along with the objectives of the research, the research method, result and discussion, conclusion and recommendations

\section{Empirical Studies}

Real estate investment requires active participation by individual investors than in other investment opportunities. At individual level, constant property maintenance is a necessity for enhanced real estate investments returns. Property maintenance focuses on sustenance and conservation of existing buildings with a view to retaining their structural stability and functionalities. It is one of the routine duties expected of property owners whether the property is held for self occupation, production, or investment purposes. At individual level of self occupation, maintenance is commonly assumed. Where properties are held as a means of production, a combination of planned and un-planned maintenance holds way. The resulting effectiveness of maintenance depends on how far away the operation is from un-planned level and how close to or tangential to planned level. Where properties are held for investment purposes, then this management activity may be passed on to a professional agent who then applies property management principles. Effectiveness of property management depends on the proactiveness of the operators and the responsiveness of the property users.

Facilities management on the other hand is broad based incorporating maintenance management, property management but more importantly, workspace management, churn management, strategic property management and the management of support services among others (Hamer, 1988; Alexander, 1996). Obviously, facilities management appears to have now absorbed maintenance management as well as property management. It is a strategic tool that readily comes in when there is a need to re-invigorate the performance of property investment. Facilities benchmarking provides a mechanism for the spread of best practice among the hotels and for stimulating competition and innovation through comparison or total emulation of similar processes.

The College of Estate Management (1999) was of the opinion that benchmarking can be used to compare performance within companies, compare performance with other companies (whether direct competitors or non-competitors) in the same sector; compare performance with companies or organisations in other sector; compare performance with overseas companies and compare performance with other members of a benchmarking club. Facilities benchmarking will enable hotels to have a better understanding of their customers and competitors; enjoy fewer complaints and more satisfied customers; reduce waste and eliminate quality problems and reworking. Others include faster awareness of important innovations and how they can be applied profitably; achieve stronger reputation within the market and enjoy increased profit and sales turnover.

A study by Gilleard and Yat-lung (2004) established that facilities benchmarking issues are typically driven by financial, organizational, change management, and customer-related needs. The study concluded that typical facility-oriented benchmarking indicators are flexibility, effective use of space, management of maintenance, provision for a safe environment and value for money.

Milohnic and Cerovic (2007) explores the co-dependency of benchmarking and quality based on numerous interviews with 60 managers of small hotels in Croatia with the aim of stating the different ways and possibilities of using the benchmarking method as one of the modern, efficient methods which provide opportunities for adapting to the changes and needs of the modern market. The research showed that management of small hotels 
rarely compare business success between domestic and foreign competitors. For this reason, they fail to understand that doing so is a way of improving their business.

One clear area of effective management is in strategic management. Torkildsen (1992) refers to it as operational excellence that involves taking strategic decisions. This strategic approach to hotel business development is in vogue in advanced countries of the world along with facilities management, mergers and acquisition, expansion of brands, strengthening of guest loyalty, aggressive maintenance, and new technology and marketing strategy (Telfer, 2005). Effective organizations need to put in place marketing, asset management and business development strategies if they are to remain relevant in business.

Okoroh, Jones and Ilozor (2003) dwelt on adding value to constructed facilities with the aim of examining the impact of service contact on the perceived quality and nature of the accommodation package. Survey questionnaire was employed for gathering data while personal construct theory was used for analysing generated data. In their own opinion, a very large proportion of the products of hotels relates to the management of the core activities that centres on built facilities. There is a need for life cycle planning of these facilities, their capacity, use and proactive maintenance policy, as well as the resources needed to cope with changing demands. Factors such as life cycle costing, productivity analysis, performance values, and legislative change drive facilities management. In conclusion they opined that given the nature, characteristics, variety of components and related economic aspects of hotels, there are benefits to be derived from the application of facilities management values. Proactive management of service products essentially propel hotel products' sales. Thus, Okoroh, Jones and Ilozor (2003) are of the view that for hotel accommodation package to satisfy customer needs, it must be accompanied by intangible services such as security, a feeling of well-being, etc. as shown in Figure 1.

The research efforts of Okoroh, Jones and Ilozor (2003) were exploratory and really non-specific as far as facilities management is concerned. Accommodation support services are many with varying procurement and management techniques to obtain maximum returns on investment.

Wai (2004) investigated the extent of and barriers to the application of facilities management and hotel renovations in Hong Kong. He was of the view that facilities management strategies could be applied to hotel renovations to minimize disturbances to occupiers in residence and thus ensure smoothness in meeting time, quality and cost requirements. Using survey research with two case studies and descriptive statistics for analysis the study concluded that facilities management is relatively new in Hong Kong and that research studies between facilities management and hotel renovations were unpopular. The study provides fundamental approaches to executing research on hotel assets management styles.

Briggs, Sutherland and Drummond (2007) examined the importance of tourism to Scotland, the criticality of the hotel sector to its growth and the link between service quality and business profitability. The study thus examined service quality across all hotels in Scotland to establish managements' and customers' current perceptions of service quality performance. Using survey research and descriptive analysis, the empirical findings indicate that service was being lost by the focus of the Scottish quality assurance (QA) scheme on tangibles and there were major inconsistencies in service quality performance across the sector. They were of the opinion that service quality in the hotel industry had been well researched in developed countries as against very little comparative research across the Scottish hotel sector. The study, though empirical, failed to examine service delivery from facilities management as well as assets management style points of view. The study however provides a guide for this study.

The empirical studies of Gilleard and Yat-Lung (2004); Okoror, Jones and Ilozor (2003); Wai (2004); Milohnic and Cerovic (2007), focussed on service management from facilities management perspective without first establishing the assets management styles prevailing within the hotel industry. Besides, the studies are pedagogic and not in line with the local peculiarities of Nigeria. This current study is set to identify the asset management styles prevalent in the hotel sector within the Nigerian economy.

\section{Research Method}

This research is an exploratory cross-sectional survey devoid of control but a one-time observation of independent and non-manipulated variables. The study covers the South-western geo-political zone of Nigeria. The zone consists of six States namely Lagos, Ekiti, Ogun, Oyo, Osun and Ondo as reflected in Fig. 2. The six States are contiguous and with similar characteristics. These attributes allow for easy comparability. Hotels selected for this study are those that meet the National Classification and Grading of Hotels standard as published by Nigeria Tourism Development Corporation (2001). Table 1 contains the summary of the stipulated standards. The State capitals as shown in Table 2 are thus selected because in comparing them with other cities, they are considered to be one of the most important and best-known tourist destinations within each State. 
However, the relatively low figure for hotels in Akure and Oshogbo might be due to their hinterland status and agricultural economy.

In search for an acceptable sample size for this study, the researcher adopts Kothari's (1978) formula by adopting a $95 \%$ confident level and a $0.02 \%$ probable error of using a sample rather than surveying the whole population. By this method, a sample size of 57 was obtained and this figure was split among the States based on the number of hotels within each State as reflected in Table 3. Hotel selection for the distribution of questionnaire was based on randomization principle (Asika, 1991). Self-administered questionnaires complemented with in-depth personal interview and physical survey of the constructed facilities was used for data generation. Descriptive statistics was employed for statistical analysis.

\section{Results and Discussion}

Out of the 57 questionnaires distributed, only 28 questionnaires were retrieved (49\%) and found useful for the exercise. Table 4 shows the summary of the responses to the question on prevailing hotel property asset management styles. Fifty seven percent of hotel management adopts maintenance management. Maintenance management topping the list could be attributed to conservatism or the belief in its efficacy. Facilities bench marking scoring $25 \%$ could be attributed to the desire of hotel management to try new ways so as to avoid losing out completely. The result from in-depth interviews showed that non-acceptance of property management is due largely to the fact that hoteliers prefer to run their hotels themselves.

For further clarification, as can be seen in Table 5, maintenance management practice cuts across all the categories of hotels studied. Facilities management practice is employed only among the 5-Star hotel proprietors while facilities bench marking is found among 4 to 5 -Star hotel proprietors. Only $36 \%$ of the studied hotels have embraced either full blown facilities management system or practice facilities benchmarking.

This finding supports earlier observation of Wai (2004) who opined that facilities management is a new idea in hotel management and renovation. At the same time, the finding runs contrary to Alexander's (1996) averment that only by being tuned to business objectives and married to a strategic plan can organizations encourage innovation and enterprise. It is however important for hotel managers to exploit new ways of doing things especially if such would add value to the organization's process and improve its effectiveness.

\section{Conclusion and Recommendation}

As observed from the findings so far, the disposition of hoteliers in Nigeria towards adoption of facilities management is poor. It is only hotel managers of 5-star hotels that have fully embraced the latest style of hotel assets management. Although the finding in Croatia by Milohnic and Cerovic (2007) that smaller hotels' managements are irresponsive to change aligns with the findings, however, it negates the proposition of Telfer (2005) that success in today's hotel management is driven by high responsiveness to adoption of new ways of doing things. The adoption of facilities management by hotel organizations, whether large or small, is one major way of seeing the impact of strategic change in Nigerian hotels. It is envisaged that the best practice of facilities management will cost money but avoiding or delaying it may be extremely expensive in the end. The Nigerian Tourism Development Corporation should develop a framework for quality assurance policy improvement among hotels in Nigeria. By so doing, hotel management companies and intending property development and management companies would be guided and influenced into doing things beyond the benchmark.

\section{References}

Akintola - Arikawe, J.O. (2002). State Survey of Lagos in Mamman, A. B, Oyebanji, J.O, and Peters, S.W (Eds.). Nigeria: A People United, A Future Assured. Vol. 2. Survey of States $2^{\text {nd }}$ ed. (pp. 379-380). Abuja: Federal Ministry of Information.

Akintola - Arikawe, J.O. (2002). State Survey of Ekiti State. In Mamman, A. B, Oyebanji, J.O, and Petters, S.W (Eds.). Nigeria: A People United, A Future Assured. Vol. 2Survey of States $2^{\text {nd }}$ ed. (pp. 430-433). Abuja: Federal Ministry of Information.

Alexander, K. (1996). Facilities Management: Overview. In Alexander, K [Ed.]._Facilities Management London: Theory and Practice(pp. 1-12). LondonE \& FN Spon.

Alexander, K. (2003). A Strategy for Facilities Management. Facilities, 21(11/12) 269 - 274.

Arditi, D and Nawakorawit, M. (1999). Issues in Building Maintenance: Property Managers' Perspective. Journal of Architectural Engineering, December 117-132.

Asika, N. (1991). Research Methodology in the Behavioral Sciences $1^{\text {st }}$ Ed. Lagos: Longman Nigeria Plc. 
Barrett, P. (2000). Achieving Strategic Facilities Management through Strong Relationships Facilities $18(10 / / 11 / 12) 421-426$.

British Standards Institution BS 3811. (1964). Glossary of General Terms used in Maintenance Organizations (H.M.S.O., 1964).

Briggs, S; Sutherland, J and Drummond, S. (2007). Are Hotels Serving Quality? An Exploratory Study of Service Quality in the Scottish Hotel Sector. Tourism Management 28(2007) $1006-1019$. www.elsevier.com/locate/tourman.

Bode-Thomas, A. I. (2003). Nigerian Hotels Have Improved. The Guardian Newspapers, Friday, September 12, 2003, 20(9,061), P.51College of Estate Management. (1995). Property Management. Whiteknights, Reading: The College of Estate Management.

College of Estate Management. (1999). People and Quality Management. Whiteknights, Reading. The College of Estate Management.

Ekanade, O. (2002). State Survey of Ondo State. In Mamman, A. B, Oyebanji, J.O, and Petters, S.W [Eds.). Nigeria: A People United, A Future Assured.Vol. 2.Survey of States $2^{\text {nd }}$ Ed. (pp. 444). Abuja: Federal Ministry of Information.

Fadare,S. O. (2002). State Survey of Osun State. In Mamman, A. B, Oyebanji, J.O, and Petters, S.W (Eds.). Nigeria: A People United, A Future Assured._Vol. 2. Survey of States $2^{\text {nd }}$ ed. (pp. 453). Abuja: Federal Ministry of Information.

Gilleard, J and Yat-lung, P. (2004). Benchmarking Facility Management: Applying Analytic Hierarchy Process. Facilities $22(1 / 2) 19-25$.

Hamer, J.M. (1988). Facility Management System, $1^{\text {st }}$ Ed, New York: Van Nostrand Reinhold Inc.

Hassanien, A and Losekoot, E. (2002). The Application of Facilities Management Expertise to the Hotel Renovation Process. Facilities, 20(7/8) 230 - 238.

Kinnear, P.R and Gray, C.D. (2000). SPSS for Windows Made Simple, Release 10. Hove East Sussex, UK: Psychology Press Ltd, Publishers.

Kothari, C.R. (1978). Quantitative Techniques $3^{\text {rd }}$ Ed. New Delhi: Vikas Publishing House PVT Ltd.

Nigerian Tourism Development Corporation (NTDC). (2001). Standard for National Classification and Grading of Hotels and Other Serviced Accommodations in Nigeria. $1^{\text {st }}$ Ed. Abuja: Nigerian Tourism Development Corporation.

Milohnic, I and Cerovic, Z. (2007). Benchmarking and Quality of Small Hotels in Croatia: An Explorative Study. Management 2 (1): 25 - 35.

Nwankwo, P.C. (2004). Property Management Practice in Nigeria, $2^{\text {nd }}$ Ed. Lagos: B.G Company.

Ogunjumo, A. (2002). State Survey of Lagos in Mamman, A. B, Oyebanji, J.O, and Petters, S.W (Eds.). Nigeria: A People united, A Future Assured._Vol. 2. Survey of States $2^{\text {nd }}$ ed. (p. 471). Abuja: Federal Ministry of Information.

Okewole,I.A. (2002). State survey of Oyo State. In Mamman, A. B, Oyebanji, J.O, and Petters, S.W (Eds.). Nigeria: A People United, A Future Assured. Vol. 2. Survey of States $2^{\text {nd }}$ ed. (p. 429). Abuja: Federal Ministry of Information.

Okoroh, M.I; Jones, C.M and Ilozor, B.D. (2003). Adding Value to Constructed Facilities: Facilities Management Hospitality Case Study. Journal of_Performance of Constructed Facilities, February 24-33.

Okungbowa, A. I. (2005). Tourism 2004: Still Cruising on the Slow Lane. The Guardian Newspapers, Friday, January 7, 21(9), 31, 36.

Olusola-Obasa, B. (2005). Customers Groan under Poor Hotel Services. The Punch Newspapers, November 10, pp19.

Oluwalana, F. (2005). It's Better to Own the Property for Your Hotel Business. The Punch Newspapers, Saturday, December 17, 37(12), 38.

Seeley, I.H. (1976). Building Maintenance $1^{\text {st }}$ Ed. London: Macmillan Publishers Ltd.

Spedding, A and Holmes, R. (1999). Facilities Management. in Spedding [Ed.] CIOB Handbook of Facilities Management (pp. 1-8). London: Longman Group Ltd. 
Telfer, A. (2005). Hotel Supply Chain: A Strategic Approach. European Hotel Managers Association. http://www.hilton.com

Then, D.S. (2000). The Role of Real Estate Assets in Supporting the Fulfillment of Corporate Business Plans: Key Organizational Variables for an Integrated Resource Management Framework. Facilities, 18(7/8), 273-281

Thomas, B. (2003). Nigerian Hotels Have Improved" The Guardian Newspapers, Friday, September 12, pp 51.

Torkildsen, G. (1992). Leisure Recreation Management $3^{\text {rd }}$ Ed. London: E \& FN Spon.

Wai. K.C. (2004). The Application of Facilities Management to Hotel Renovations in Hong Kong. www.hub.hku.hk/handle/123456789/48845

Table 1. Classification and Grading of Hotels in Nigeria

\begin{tabular}{|c|c|c|}
\hline Hotel & $\begin{array}{l}\text { Minimum } \\
\text { Letting Rooms }\end{array}$ & Facilities and Services expected \\
\hline 1-star & 10 & $\begin{array}{l}\text { Limited meal services } \\
\text { Budget oriented accommodation } \\
\text { Bedrooms with/without attached bathrooms }\end{array}$ \\
\hline 2-Star & 20 & $\begin{array}{l}\text { Reasonable level of comfort in terms of meals and other amenities for gusts. } \\
\text { Reasonable level of comfort in terms of meals and other amenities for gusts. }\end{array}$ \\
\hline 3-Star & 30 & $\begin{array}{l}\text { Reasonable level of comfort in terms of meals and other amenities for gusts and } \\
\text { visitors } \\
\text { Reasonable level of comfort in terms of meals and other amenities for gusts. }\end{array}$ \\
\hline 4-Star & 40 & $\begin{array}{l}\text { High standards of furnishing } \\
\text { High level of comfort in terms of meals and other amenities for guests and } \\
\text { visitors }\end{array}$ \\
\hline 5-Star & 50 & $\begin{array}{l}\text { Impeccable services and extensive amenities of international standard for guests } \\
\text { and visitors }\end{array}$ \\
\hline
\end{tabular}

Source: Compilation based on Nigeria Tourism Development Corporation (2001)

Table 2. Hotel Distribution among State Capitals

\begin{tabular}{|c|c|c|c|c|}
\hline \multirow[t]{2}{*}{ State } & \multirow[t]{2}{*}{ State Capital } & \multirow{2}{*}{$\begin{array}{l}\text { Hotels per } \\
\text { State }\end{array}$} & Hotels & \multirow{2}{*}{$\begin{array}{l}\text { \%age of hotels in } \\
\text { State Capital }\end{array}$} \\
\hline & & & $\begin{array}{l}\text { in each State } \\
\text { capital }\end{array}$ & \\
\hline Ekiti & Ado-Ekiti & 35 & 13 & 37 \\
\hline Lagos & Ikeja & 42 & 29 & 69 \\
\hline Ogun & Abeokuta & 39 & 11 & 28 \\
\hline Ondo & Akure & 22 & 8 & 36 \\
\hline Osun & Oshogbo & 18 & 3 & 17 \\
\hline Oуо & Ibadan & 26 & 16 & 62 \\
\hline
\end{tabular}


Table 3. Derivation of sample Size

\begin{tabular}{llll}
\hline \multicolumn{1}{c}{ Study Population } & Sample Frame & Sample Size \\
State Capital & & & \\
\hline Ado-Ekiti & 35 & 13 & 9 \\
Ikeja & 42 & 29 & 20 \\
Abeokuta & 39 & 11 & 8 \\
Oshogbo & 18 & 3 & 3 \\
Ibadan & 26 & 6 & 11 \\
Total & 182 & 80 & 57 \\
\hline
\end{tabular}

Table 4. Prevailing Property Asset Management Styles among Hotels in Nigeria

\begin{tabular}{llll}
\hline Management Style & Frequency & $\%$ & Cum. \% \\
\hline Maintenance Management & 16 & 57 & 57 \\
Property Management & 2 & 7 & 64 \\
Facilities Bench Marking & 7 & 25 & 89 \\
Facilities Management & 3 & 11 & 100 \\
\hline
\end{tabular}

Table 5. Hotels and their Property Assets Management Styles

\begin{tabular}{|c|c|c|c|c|}
\hline Hotel Class & Maintenance Mgt & Property Mgt & Facilities Mgt & Facilities Benchmarking \\
\hline \multirow[t]{3}{*}{ 2-Star } & Niger Palace Hotel & Hotel Plaza & & \\
\hline & Heritage Hotel & Oasis Hotel & & \\
\hline & Universal Hotel & & & \\
\hline \multirow[t]{12}{*}{ 3-Star } & West-end Hotel & & & \\
\hline & Olujoda Hotel & & & \\
\hline & Kilo Hotel & & & \\
\hline & Bluenet Hotel & & & \\
\hline & Hotel Newcastle & & & \\
\hline & Lafia Hotel & & & \\
\hline & Greenspring Hotel & & & \\
\hline & D'Erovan Hotel & & & \\
\hline & Adesba Hotel & & & \\
\hline & K.S. Motel & & & \\
\hline & Dusmar Hotel & & & \\
\hline & $\begin{array}{l}\text { Leisure Spring } \\
\text { Hotel }\end{array}$ & & & \\
\hline \multirow[t]{3}{*}{ 4-Star } & Owena Motel & & & Excellence Hotel \\
\hline & & & & Kakanfo Hotel \\
\hline & & & & MicCom Gulf Hotel \\
\hline \multirow[t]{4}{*}{ 5-Star } & & & Federal Palace Hotel & Mainland Hotel \\
\hline & & & Lagos Sheraton Hotel & Gateway Hotel \\
\hline & & & L"Ekomeridian Hotel & Lagos Airport Hotel \\
\hline & & & & Premier Hotel \\
\hline Total & 16 & 2 & 3 & 7 \\
\hline \multirow[t]{3}{*}{$\%$} & 57 & 7 & 11 & 25 \\
\hline & A & $\mathrm{B}$ & $\mathrm{C}$ & $\mathrm{D}$ \\
\hline & & & \multicolumn{2}{|c|}{$C+D=36 \%$} \\
\hline
\end{tabular}




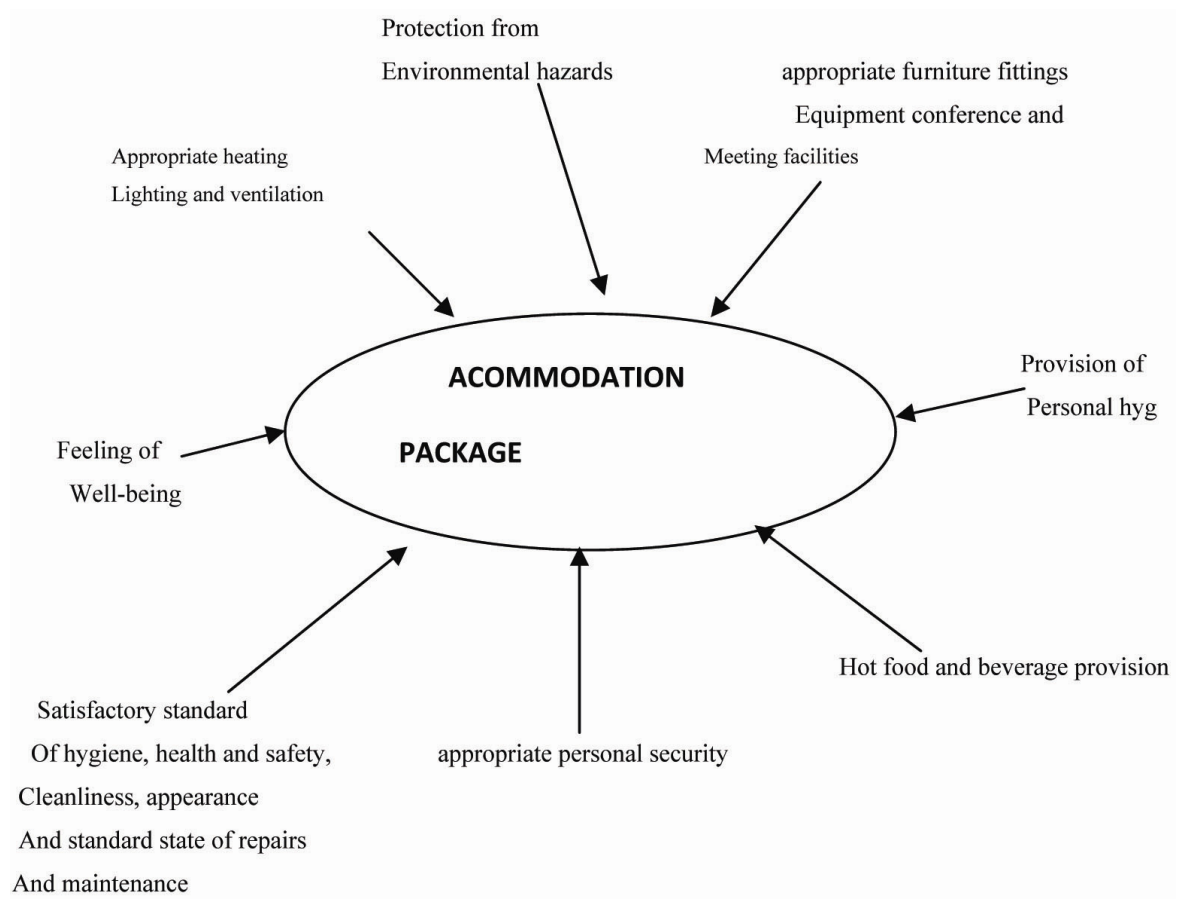

Figure 1. Hotel Accommodation Package

Source: Okoroh, Jones and Ilozor (2003) 
Map of the Federal Republic of Nigeria

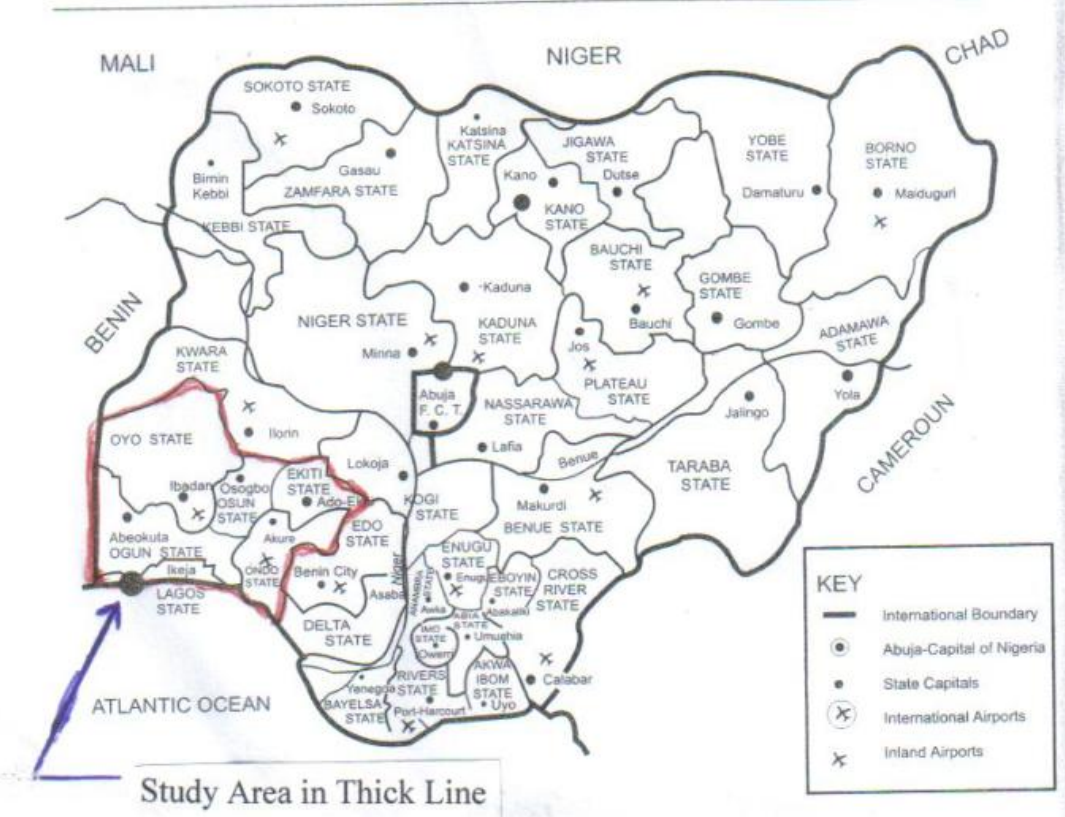

The Six Political Zones of Nigeria (States and Capital)

\begin{tabular}{|c|c|c|c|c|c|}
\hline NORTH EAST & NORTH WEST & NORTH CENTRAL. & SOUTH EAST & SOUTH WEST & SOUTH SOUTH \\
\hline $\begin{array}{l}\text { ADAMAWA } \\
\text { Yola }\end{array}$ & $\begin{array}{l}\text { JIGAWA } \\
\text { Dutse }\end{array}$ & $\begin{array}{l}\text { BENUE } \\
\text { Makurdi }\end{array}$ & $\begin{array}{l}\text { ABIA } \\
\text { Umuahia }\end{array}$ & $\begin{array}{l}\text { EKITI } \\
\text { Ado-Ekiti }\end{array}$ & $\begin{array}{l}\text { AKWA-IBOM } \\
\text { Uyo }\end{array}$ \\
\hline $\begin{array}{l}\text { BAUCHI } \\
\text { Bauchi }\end{array}$ & $\begin{array}{l}\text { KADUNA } \\
\text { Kaduna }\end{array}$ & $\begin{array}{l}\text { NIGER } \\
\text { Minna } \\
\end{array}$ & $\begin{array}{l}\text { ANAMBRA } \\
\text { Awka } \\
\end{array}$ & $\begin{array}{l}\text { LAGOS } \\
\text { Ikeja }\end{array}$ & $\begin{array}{l}\text { BAYELSA } \\
\text { Yenagoa }\end{array}$ \\
\hline $\begin{array}{l}\text { BORNO } \\
\text { Maiduguri }\end{array}$ & $\begin{array}{l}\text { KANO } \\
\text { Kano }\end{array}$ & $\begin{array}{l}\text { KATSINA } \\
\text { Katsina }\end{array}$ & $\begin{array}{l}\text { EBONYI } \\
\text { Abakaliki }\end{array}$ & $\begin{array}{l}\text { OGUN } \\
\text { Abeokuta }\end{array}$ & $\begin{array}{l}\text { CROSS RIVER } \\
\text { Calabar }\end{array}$ \\
\hline $\begin{array}{l}\text { GOMBE } \\
\text { Gombe }\end{array}$ & $\begin{array}{l}\text { KEBBI } \\
\text { Birnin Kebbi }\end{array}$ & $\begin{array}{l}\text { KOGI } \\
\text { Lokoja } \\
\end{array}$ & $\begin{array}{l}\text { ENUGU } \\
\text { Enugu } \\
\end{array}$ & $\begin{array}{l}\text { ONDO } \\
\text { Akure }\end{array}$ & $\begin{array}{l}\text { DELTA } \\
\text { Asaba }\end{array}$ \\
\hline $\begin{array}{l}\text { TARABA } \\
\text { Jalingo }\end{array}$ & $\begin{array}{l}\text { SOKOTO } \\
\text { Sokoto }\end{array}$ & $\begin{array}{l}\text { KWARA } \\
\text { llorin } \\
\end{array}$ & $\begin{array}{l}\text { IMO } \\
\text { Owerri } \\
\end{array}$ & $\begin{array}{l}\text { OSUN } \\
\text { Osogbo }\end{array}$ & $\begin{array}{l}\text { EDO } \\
\text { Benin City }\end{array}$ \\
\hline $\begin{array}{l}\text { YOBE } \\
\text { Damaturu }\end{array}$ & $\begin{array}{l}\text { ZAMFARA } \\
\text { Gusau }\end{array}$ & $\begin{array}{l}\text { NASSARAWA } \\
\text { Lafia } \\
\end{array}$ & & $\begin{array}{l}\text { OYO } \\
\text { Ibadan }\end{array}$ & $\begin{array}{l}\text { RIVERS } \\
\text { Port Harcourt }\end{array}$ \\
\hline & & $\begin{array}{l}\text { PLATEAU } \\
\text { Jos }\end{array}$ & & & \\
\hline
\end{tabular}

Figure 2: The Study Area - South-Western Geo-Political Zone of Nigeria 